\title{
Several Landscapes: Bowen and the Terrain of North Cork
}

\author{
By Eibhear Walshe \\ University College Cork
}

\begin{abstract}
Copyright (c) 2005 by Eibhear Walshe. This text may be archived and redistributed in electronic form, provided that the author and journal are properly cited and no fee is charged for access. Archiving, redistribution, or republication of this text on other terms, in any medium, requires the notification of the journal and consent of the author.
\end{abstract}

\begin{abstract}
The subject of this essay is the Irish writings of the novelist Elizabeth Bowen. This essay discusses the disjunction between Elizabeth Bowen's critical writings on her family history and her fictive representations of the landscape of North Cork. Looking at her 1942 family chronicle, Bowen's Court and her childhood memoir Seven Winters, also published in 1942, the author suggests a gap between her critical perspectives on her position as an Anglo-Irish writer and her fictions on the same theme. The essay concentrates on her imaginings of the hostile landscape around her home in North Cork and the murderous intent of these Irish fields and hills, in particular in her novel, The Last September and her short story, "The Happy Autumn Fields".
\end{abstract}

Key Words: Elizabeth Bowen. The Irish Big House Novel. The Last September.

In an essay called 'Prints on the Scene: Elizabeth Bowen and the Landscape of Childhood', an essay taken from The Irish Story, Roy Forster discusses a curious episode in which Elizabeth Bowen's name was excluded from an anthology of North Cork writing —or to be more precise, her deleted name was pointedly included. In Forster's own words:

The effort to define congruent literary geography, as suggested earlier in this book, has been a recurring preoccupation in Irish cultural commentary -and it is not over yet. A mystifyingly crude version was produced in 1993 by the editor of the shadowy Aubane Historical Society's eccentric North Cork Anthology. The contents page includes the name of 'Elizabeth Dorothea Cole Bowen CBE' with a line drawn through it. The editor explains laboriously that this is to show that though some people may think Elizabeth Bowen is an Irish writer, this is not the case. "She was English ... Most of her novels are still in print due to an English demand for them". Even more damningly," she was not a North Cork writer, in the sense of being a product of North Cork society, or in being interested in it or writing about it' (Foster 2001: 148).

This attempt to deny Elizabeth Bowen her North Cork grounding is clearly doomed to failure. Her family had been settled in Farahy for nearly two hundred years by the time of her birth in 1899 and Bowen herself spent every childhood summer at Bowen's Court until her father's nervous breakdown in 1907. As an adult, Bowen divided her life between England and Farahy and, on her death in 1973, she was buried next to her husband and her father in the local churchyard. This identification with Ireland and particularly with North Cork and with the landscape around Farahy energised her as a writer, particularly at times of disturbance. In her last volume of memoirs, Pictures and Conversations, Bowen tells us: "am I not manifestly a writer for whom places loom large? As a reader, it is to the place-element that I react most strongly; for me, what gives fiction verisimilitude is its topography" (1975: 34), Bowen's topography in The Last September and A World of Love and in stories 
like "Summer Night" and "The Happy Autumn Fields" is the North Cork landscape around Bowen's Court, imaginatively transformed into a powerful, mute and devouring presence. Her imaginative debt to this landscape is made clear in Pictures and Conversations: "since I started writing, I have been welding together an inner landscape, assembled anything built at random. But if not at random, under the influence of what? ... A writer needs to have at command and recourse to, a recognisable world, geographically consistent and having for him or her super reality."(1975: 36). The fields and mountains around Farahy provided Bowen with this inner landscape, yet, despite biographical and textual evidence to the contrary, Bowen's place in an anthology of North Cork writing was denied. Why? Perhaps this denial is a response to Bowen's fact-finding activities during the Second World War, when she volunteered to provide secret reports on Ireland and Irish neutrality for the British Ministry of Information. Perhaps also a residual hostility towards her class -a hostility Bowen would have understood perfectly because, in her fiction, her imagined North Cork fields are infused with a lethal hostility.

In this essay, I want to consider the disjunction between Bowen's critical writings on the Anglo-Irish and her fictive representations of the Big House in the North Cork landscape. I agree with Roy Foster when he writes that: "When Elizabeth Bowen wrote about this part of Cork, her sense of familiar life and her love of place transcended religion, descent and political opinions... So much of her writing (and, I suspect, much of her life) concerned an effort to establish permanence." (in Walshe 1999: 21) This yearning towards a sense of permanence is at the basis of her wartime essays but, at the same time, I would suggest that Bowen's fictive writing implicitly subverts much of her critical work. At times of violence, Bowen used her learning and her sharp critical intelligence to locate solidity but her literary imagination was moved by a contradictory impulse to explode permanence. Bowen's underlying desire is to present a sinister threat of extinction lurking somewhere out there in the North Cork landscape. Her fiction reveals a darker version of her anxiously utopian vision of the fields around Farahy presented in her memoirs and essays.
Thus Foster's analysis of Bowen's wartime critical writings needs a wider contextualising - the context of her wartime fictions.

I agree with Foster when he writes: "The permanence that Bowen sought, in writing about her Irish past (while the world exploded at war all around her), required an exploration of memory - the only place where, as Proust had taught, permanence resides. A recognised landscape would take her there: that sheltered Farahy landscape from where, she wrote 'personal pain evaporates, as history evaporates"" (Foster 2001:152) Yet this very same Farahy landscape proves murderous in The Last September and again in her Irish fiction written during the Second World War. Overall, her desire for the harmonious integration of the Big House within the North Cork landscape is at odds with her fictive representations of the besieged house, cowering in the hostile fields. In Bowen's imagined fields, houses are terrorised, the light is devouring and murderous and young men die mysteriously. As an essayist, Bowen strained towards the vision of an integrated Anglo-Irish House, at ease in the fields beneath the Ballyhoura Hills. However, as a novelist, Bowen knew better.

Nowhere is Bowen's acute sense of a lone house set in a brooding landscape more strikingly represented than in her 1929 novel of the Irish War of Independence, The Last September. In this novel, Bowen idealised her Anglo-Irish protagonists for their courage in the face of imminent extinction in the hands of the emergent Irish revolutionaries. Sir Richard and Lady Naylor of Danielstown, the house at the centre of the novel, carry on the civilised forms of county life in the face of rebellion and insurrection and defend their traditional feudal relationship with the native Irish. Both Naylors resent the enforced protection of the British Army and refuse to acknowledge that the life in the Irish Big House is, in the indiscreet words of their nephew, Laurence "rolling up rather" (25). However, throughout the narrative, Bowen displaces the Anglo-Irish dread of attack and extinction away from the native Irish themselves and onto the North Cork landscape. This is particularly evident in this description of the Big House, Danielstown, glimpsed at a distance by the protagonist, Lois:

To the south, below them, the demesne trees of Danielstown made a dark formal square 
like a rug on the green country. In their heart, like a dropped pin, the grey glazed roof reflecting at the wide, light, lovely, unloving country, the unwilling bosom whereon it was set, the sky lightly glinted. Looking down it seemed to Lois they lived in a forest; spaces of lawns blotted out in the pressure and dusk of trees. She wondered they were not smothered; then wondered still more that they were not afraid. Far from here too, their isolation became apparent. The house seemed to be pressing down low in apprehension, hiding its face, as though it had her vision of where it was. It seemed to gather its trees close in fright and amazement set. (66)

Commenting on this passage, Julian Moynahan (1995: 242) makes the point that "The deliberate anthropomorphism brings out the pathos of the beleaguered, beautiful lonesome tradition that the natives are struggling to be rid of. She sees the estate as a jewel; others, spying from the mountains and attacking from under the protective dusk of dense trees, see instead the chains by which jewels like Danielstown hung upon the unwilling bosom of the country."

The Last September may be Bowen's elegy for the fall of the Anglo-Irish and the loss of a civilisation but the overt conflict within the narrative arises from the mutual incomprehension between the Anglo-Irish and the visiting British military. Much of the social comedy of the novel comes from the distaste felt by Lady Naylor for her socially inferior English defenders: "I always find the great thing in England is to have plenty to say, and mercifully they are determined to find one amusing. But if one stops talking, they tell one the most extraordinary things, about their husbands, their money affairs, and their insides.'(134) Beneath Lady Nalyor's puzzled contempt for the English lies a steely determination to prevent the marriage of her niece Lois with the young officer, Gerald Lesworth. The threat posed by this English youth of unknown bourgeois stock is much greater for Lady Naylor than the covert activities of the local Irish freedom fighters. Lady Naylor succeeds in breaking the engagement between her niece and the young English officer but is imaginatively implicated, to some degree, with Lesworth's subsequent murder at the hands of the local IRA. These shadowy, unnamed figures are the real threat to Danielstown and the landscape is the visible signifier of this anonymous threat. At an early point in the novel, Lois encounters a solitary IRA man walking through her uncle's desmesne late at night. This faceless Irish revolutionary is characterised by resolve, anonymity and stealth and is a visible warning of doom for the house: "The trench coat rustled across the path ahead, to the swing of a steady walker. She stood by the holly immovable, blotted out in her black, and there passed within reach of her hand, with the rise and fall of a stride, a resolute profile, powerful as a thought. In gratitude for its fleshliness, she felt prompted to make some contact: not to be known seemed like a doom: extinction."(134) Lois is ignored by this unnamed, resolute profile but the house clearly fears the lone revolutionary as a harbinger of execution: "The crowd of trees, straining up from passive disputed earth, each sucking up and exhaling the country's essence - swallowed him finally...Below, the house waited; vast on its west side, with thin yellow lines round the downstairs shutters. It had that excluded, sad, irrelevant look outsides of houses take in the dark." (134).

In the closing moments of the novel, Bowen allows this violence to emerge with shocking force with the murder of the house:

For in February, before those leaves had visibly budded, the death - execution, rather - of the three houses, Danielstown, Castle Trent, Mount Isabel, occurred in the same night. A fearful scarlet ate up the hard spring darkness: indeed, it seemed that an extra day, unreckoned, had come into abortive birth that these things might happen. It seemed, looking from east to west at the sky tall with scarlet, that the country itself was burning; while to the north the neck of mountains before Mount Isabel was frightfully outlined. The roads in unnatural dusk ran dark with movement, secretive or terrified; not a tree, brushed pale by wind from the flames, not a cabin pressed in despair to the bosom of the night, not a gate too starkly visible but had its place in the design of order and panic. At Danielstown, halfway up the avenue, the thin iron gate twanged (missed its latch, remained swinging aghast) as the last unlit car slid out with the executioners bald from accomplished duty. The sound of the last car widened, gave itself to the open and empty country and was demolished. Then the first wave of a silence that was to be ultimate flowed back, confidant, to the steps. Above 
the steps, the door stood open hospitably upon a furnace. (206)

This novel represents Bowen's most sustained engagement with Ireland but it must be remembered that few of her other novels draw on her own country for inspiration. Her novels of the nineteen-thirties, To The North, Friends and Relations and her most celebrated novel, The Death of the Heart all had English settings and English characters and it is not until the Second World War that Bowen turns her fictive and critical attention back to Ireland again.

Times of violence were also times of intense creativity for Bowen. As she put it herself: "During the war I lived, both as a civilian and as a writer, with every pore open... arguably, writers are always slightly abnormal people: certainly in so-called 'normal' times, my sense of the abnormal has been very acute. In war, this feeling of slight differentiation was suspended: I felt one with and just like, everyone else...We all lived in a state of lucid abnormality." (The Demon Lover 1947: 190) Out of this lucid abnormality came a flood of writing about Ireland: Bowen's Court and Seven Winters in 1942, and stories like "The Happy Autumn Fields" in 1945. In all of these Irish writings, Bowen looked homewards to North Cork as a place of stability and loyalty in an endangered and treacherous world and her vision of AngloIreland becomes her talisman, her source for imaginative power and stability in wardisordered London. However, unease continues to lurk out in the North Cork terrain. The tensions of being Anglo-Irish at a time when Britain was at war while Ireland remained neutral accentuated Bowen's ambivalent attitude towards Ireland. In the words of the critic, Heather Bryant Jordan (1992: 100): "Unable to abandon her colonial training, Bowen found herself in the midst of a battle with institutions that echoed her own skirmishes with herself." These skirmishes meant that, even in her most celebratory work, her childhood memoir, Seven Winters, she still writes of her birth in the following terms: "So by having been born where I had been born in a month in which that house did not exist, I felt that I had intruded on some no-place." (1945: 7).

To compensate, Bowen's critical writings of the early 1940's show her at her most determinedly optimistic. The best example of this kind of writing comes with her 1942 essay 'The Big House'; first published by her friend and lover, Sean O'Faolain, in his pluralist journal, The Bell. O'Faolain founded this magazine to counterbalance the oppressive cultural insularity and xenophobia of Ireland in the 1930's and 1940's and he invited Bowen to speak up, as it were, for the marginalised and antagonistic Anglo-Irish of post-independence Ireland. Bowen seized this opportunity to argue for a valid place for the Anglo-Irish in contemporary Ireland. Thus her essay is a plea for assimilation, a utopian vision of a harmonious relationship between house and landscape. Her tone throughout the piece is jaunty: "The loneliness of my house, as of many others, is more an effect than a reality ... When I visit other big houses I am struck by some quality that they all have — not so much isolation as mystery ... they were planned for spacious living - for hospitality above all." (in Walshe 1999: 61) Yet, despite her need to create a place for the Big House in 20th century Ireland, her particular sense of the strangeness of the Big House within the countryside inevitably breaks through in this essay: "The Big House people were handicapped, shadowed and to an extent queered by their pride, by their indignation at their decline and by their divorce from the countryside in whose heart their struggle was carried out." (63) She concludes her essay with a call for political and cultural accommodation between Big House and surrounding towns and villages: "The Big House has much to learn - and it must learn if it is to survive at all. But it also has much to give. From inside many big houses (and these will be the survivors) barriers are being impatiently attacked. But it must be seen that a barrier has two sides." (65).

At the same time, Bowen's most ambitious wartime writing on Ireland was a history of her family home, Bowen's Court. In this family chronicle, she proudly presents successive Bowen patriarchs and landowners as members of a powerful dynasty and addresses the difficult question of attempted harmonisation between house with surrounding lands. However, blankness and non-being threatened to descend on the Big House and the threat of violence is never quite exorcised: "inside and about the house and in the demesne woods you feel transfixed by the surrounding emptiness; it gives depth to the 
silence, quality to the light. The land around Bowen's Court, even under its windows, has an unhumanised air the house does nothing to change. Here are, even, no natural features, view or valley to which the house may be felt to relate itself. It has set, simply, its pattern of trees and avenues on the virgin, anonymous countryside." (1998: 21) As Hermione Lee writes of Bowen's Court:

It is the story of what happens to a minority when they lose the confidence, which enabled them to build, as they did in the eighteenth century. It describes a 'big' impersonal, dignified concept of living - traditional sanctity and loveliness' - going into retreat. So Bowen's Court is intimately related to Bowen's fiction, all of which is concerned with how to live in a world where rootedness, acquisitions, permanence - the Burkean 'goods'are at risk, and where a decorous idea of behaviour has degenerated into the dire period of Personal Life. (1999:31)

In her descriptions of the land surrounding the North Cork towns of Doneraile and Mallow, the risky business of attempting to locate permanence is to the forefront of her mind. For example, she describes Edmund Spenser's time in Ireland in terms that have little or no basis in historical fact and show some slight sense of Spenser's own writings on Ireland. Rather she reflects her own interaction with the Irish landscape:

He liked little in Ireland: his position was sinister and desolate...his castle, Kilcolman, lies two miles north-west of Doneraile, on an exposed plateau under the Ballyhouras; the marsh where gulls breed was once his smiling lake — but he never cared for its smile. Kilcolman keep, a torn-open ruin, still stands; winds race round it at every time of year. The view is of Ireland at its most intimidating - the marsh, the heartless mountains with their occasional black frown. The landscape fulfilled, for Spenser, its conveyed threat; the castle was burnt by the Irish in his absence, and one of his sons, an infant, died in the fire. (7)

In contrast, her 1949 novel The Heat of the Day has a long section set in Ireland and, in this fictionalised version of the Irish Big House, she allows a sense of untroubled patriotic love between house and land to predominate. This is of a piece with Bowen's wartime sense of Anglo-Ireland as a loyal, stable place and the Anglo-Irish home becomes symbolically implicated with eventual allied victory. In the novel, Stella Rodney, the protagonist, visits Mount Morris, the house inherited by her soldier son. During her stay in Ireland, Stella comes to see this Irish Big House as an oasis of feudal certainty and this certainty is contrasted unfavourably with the suffocating, traitorous suburban villas of the English Home Counties. Mount Morris is viewed by Stella in terms that contrast Lois' troubled vision of Danielstown: "The river traced the boundary of the lands: at the Mount Morris side, it has a margin of water-meadow into which the demesne woods, dark at their base with laurels, ran down in a series of promontories. This valley cleavage into a distance seemed like an offering to the front window: in return the house devoted the whole muted fervour of its being to a long gaze. Elsewhere rising woods or swelling uplands closed Mount Morris in." (155). While in Ireland, Stella discovers that her lover is a spy and a traitor and she returns to London intent on confronting him. In addition, Mount Morris is the place where Stella first hears of Allied victories in North Africa, the turning point of the war. So, it seems as if Anglo-Ireland has been transmuted into a loyal, safe and trustworthy terrain by the experience of the Second World War.

However, to unsettle this possibility I want to conclude this essay by considering one of Bowen's other war time writings on Ireland, her story "The Happy Autumn Fields" and I want to suggest that in this story, the murderous fields around Farahy still hold threat. This 1945 short story, published in the collection The Demon Lover and Other Stories seems, at first glance, to be at one with The Heat of the Day, an idealised vision of AngloIreland from the perspective of Blitz London. Instead I want to argue that the story can be read as a reprise of The Last September. "The Happy Autumn Fields" centres on the hallucinations of the protagonist, Mary, slumbering in a damaged house in war-torn London. Mary is in mortal danger while she remains in the crumbling house, but she refuses to leave, addicted to her daydreams of a Victorian landlord and his family in an autumnal rural landscape. Throughout the story, a disparity is established between 
diminished, un-heroic wartime London and the idyllic past of Anglo-Ireland. As Mary complains: "We only know inconvenience now, not sorrow. Everything pulverises so easily now because it is rot-dry; one can only wonder that it makes so much noise. The source, the sap must have dried up, or the pulse must have stopped, before you and I were conceived. So much flowed through people; so little flows through us. All we can do is imitate love or sorrow." (1947: 112.) Mary dreams of this unnamed landscape, the prosperous autumn fields of a country house in September, another last September. In these fields, the Victorian patriarch walks the land with his numerous sons and daughters on the day his older sons return to boarding school. Mary imagines herself into the mind of Sarah, one of the many daughters of the landlord, possessively engrossed with her twin sister, Henrietta. The mood of these autumn fields, as seen through Sarah's eyes, is elegiac: "She recognised the colour of valediction, tasted sweet sadness, while from the cottage inside the screen of trees wood-smoke rose melting pungent and blue." (95) [Although the big house is never actually identified as Ireland, Bowen herself dubbed this landscape of her wartime Irish fictions "Unshakeably County Cork" (Glendinning 1978: 6)] As in The Last September, these young Anglo-Irish women, Sarah and Henrietta catch an unexpected glimpse of their home from a distance and the vulnerability of the Big House becomes immediately apparent: "The shorn uplands seemed to float on the distance, which extended dazzling to tiny blue glassy hills. There was no end to the afternoon, whose light went on ripening now they had scythed the corn... Only screens of trees intersected and knolls made islands in the vast fields. The mansion and the home farm had sunk forever below them in the expanse of woods, so that hardly a ripple showed where the girls dwelled." (1947: 97)

To some degree, this is a ghost story or at least a story about the mysterious death of a young man alone in these autumn fields. In the story, Mary dreams herself into Sarah's psyche and shares her terror and jealously at the arrival of the young man, Eugene, who has come to court and marry Henrietta. Eugene's untimely death, like that of Gerard Lesworth, prevents an unsuitable marriage and, again, is implicitly connected with sinister aspects of the North Cork landscape. Here, Bowen uses the menacing silent presence of the rooks to suggest imminent extinction: "Behind them, rooks that had risen and circled, sun striking blue from their blue black wings, plane one by one to the earth and peck again. ... In the inevitable silence rooks on the return from the fields could be heard streaming over the house; their sounds filled the sky and even the room, and it appeared so useless to ring the bell that Henrietta stayed quivering by Mamma's chair." (94; 109)

The story ends with the obliteration of the interloping young suitor by the landscape. Again, the fields around Farahy manage to accomplish their silent, murderous purpose: "Fitzgeorge refers, in a letter to Robert written in his old age, to some friend of their youth who was thrown from his horse and killed, riding back after a visit to their home. The young man, whose name doesn't appear, was alone; and the evening, which was in autumn, was fine though late. Fitzgeorge wonders, and says he will always wonder, what made the horse shy in those empty fields." (113)

\section{REFERENCES}

Bowen, Elizabeth. 1987 (1929). The Last September. London: Penguin.

Bowen, Elizabeth. 1975. Pictures and Conversation. London: Allen Lane.

Bowen, Elizabeth. 1947 (1945). The Demon Lover and Other Stories. London: Cape.

Bowen, Elizabeth. 1943 (1942) Seven Winters. London: Longmans.

Bowen, Elizabeth. 1998 (1942). Bowen's Court. Cork: The Collins Press.

Bowen, Elizabeth. 1950 (1949) The Heat of the Day. London: Cape.

Forster, Roy. 2001. The Irish Story. London: Penguin.

Glendinning, Victoria (ed.). 1978. Elizabeth Bowen's Irish Stories. Dublin: Poolbeg.

Jordan, Heather Bryant. 1992. How Will the Heart Endure. Ann Arbor: The University of Michigan. 
Lee, Hermione. 1999. Elizabeth Bowen. London: Vintage.

Moynahan, Julian. 1995. Anglo-Irish: The Literary Imagination in a Hyphenated Culture. Princeton: Princeton University Press.

Walshe, Eibhear (ed.). 1999. Elizabeth Bowen Remembered. Dublin: Four Courts. 